\title{
Are all bony fishes oxygen regulators? Evidence for oxygen regulation in a putative oxygen conformer, the swamp eel Synbranchus marmoratus
}

Svendsen, M.B.S.; Johansen, J. L.; Bushnell, P.G.; Skov, Peter Vilhelm; Norin, Tommy; Domenici, P.; Steffensen, John Fleng; Abe, A.

Published in:

Journal of Fish Biology

Link to article, DOI:

$10.1111 / \mathrm{jfb} .13861$

Publication date:

2019

Document Version

Peer reviewed version

Link back to DTU Orbit

Citation $(A P A)$ :

Svendsen, M. B. S., Johansen, J. L., Bushnell, P. G., Skov, P. V., Norin, T., Domenici, P., Steffensen, J. F., \& Abe, A. (2019). Are all bony fishes oxygen regulators? Evidence for oxygen regulation in a putative oxygen conformer, the swamp eel Synbranchus marmoratus. Journal of Fish Biology, 94(1), 178-182.

https://doi.org/10.1111/jfb.13861

\section{General rights}

Copyright and moral rights for the publications made accessible in the public portal are retained by the authors and/or other copyright owners and it is a condition of accessing publications that users recognise and abide by the legal requirements associated with these rights.

- Users may download and print one copy of any publication from the public portal for the purpose of private study or research.

- You may not further distribute the material or use it for any profit-making activity or commercial gain

- You may freely distribute the URL identifying the publication in the public portal 
Are all bony fishes oxygen regulators? Evidence for oxygen regulation in a putative oxygen conformer, the swamp eel Synbranchus marmoratus

M.B.S. SVENDSEN ${ }^{*} \mid$ J. L.JOHANSEN² | P.G. BUSHNELL ${ }^{3} \mid$ P.V. SKOV SH $^{4}$ T. NORIN ${ }^{5} \mid$ P. DOMENICI $^{6} \mid$ J.F. STEFFENSEN ${ }^{1} \mid$ A. $\mathrm{ABE}^{7}$

${ }^{1}$ Marine Biological Section, Department of Biology, University of Copenhagen.

Strandpromenaden 5, Elsinore, Denmark.

${ }^{2}$ Marine Biology Laboratory, New York University -Abu Dhabi, Saadiyat Island, Abu Dhabi,

UAE

${ }^{3}$ Department of Biological Sciences, Indiana University South Bend, South Bend, IN, U.S.A.

${ }^{4}$ Technical University of Denmark, DTU Aqua, Section for Aquaculture, The North Sea

Research Centre, Hirtshals, Denmark.

${ }^{5}$ Technical University of Denmark, DTU Aqua: National Institute of Aquatic Resources, Kgs. Lyngby, Denmark.

${ }^{6}$ IAMC-CNR, Istituto per l'Ambiente Marino Costiero, Consiglio Nazionale delle Ricerche, Località Sa Mardini, Torregrande, Oristano, Italy.

${ }^{7}$ São Paulo State University, São Paulo Unesp, Biosciences Institute, Department of Zoology, Rio Claro, SP, Brazil

\section{Correspondence}

M.B.S. Svendsen, Marine Biological Section, Department of Biology, University of Copenhagen. Strandpromenaden 5, 3000 Elsinore, Denmark.

This article has been accepted for publication in the Journal of Fish Biology and undergone full peer review but has not been through the copyediting, typesetting, pagination and proofreading process, which may lead to differences between this version and the Version of Record. Please cite this article as doi: 10.1111/jfb.13861

This article is protected by copyright. All rights reserved. 
Email: mortenbosvendsen@gmail.com; +45 23235265

\title{
Funding information
}

The project was financially supported by an international collaboration grant from the Danish Council for Independent Research.

\begin{abstract}
This study investigated the oxygen consumption of the putative oxygen conformer marbled swamp eel Synbranchus marmoratus during progressive hypoxia. Earlier studies have not reached agreement on whether $S$. marmoratus is a conformer or regulator. Our results support the view that $S$. marmoratus is an oxygen regulator, like most bony fishes.
\end{abstract}

Most bony fishes (Teleostii) are hypothesized and shown to be oxygen regulators (Ultsch et al., 1981; Steffensen, 2006), whereby they maintain their oxygen consumption during progressive hypoxia until the ambient partial pressure of oxygen becomes too low and the fish reach their critical oxygen tension, $\mathrm{pO}_{2 \text { crit }}\left(\right.$ Tang, 1933). Below $\mathrm{pO}_{2 \text { crit }}$, aerobic metabolic rate cannot be maintained and the fish becomes an anaerobic oxygen conformer as its oxygen consumption decreases with environmental oxygen. A few species of teleosts have been suggested to be oxygen conformers. These species, which include the marbled swamp eel Synbranchus marmoratus Bloch 1795, in addition to inanga Galaxias maculatus (Jenyns 1842), sturgeons

This article is protected by copyright. All rights reserved. 
Acipenser spp., walking catfish Clarias batrachus (Hamilton 1822), and plainfin midshipman Porichthys notatus Girard 1854 (Singh \& Hughes, 1971; Graham \& Baird, 1984; Urbina et al., 2012; Tripathi et al., 2013; Craig et al., 2014; LeMoine et al., 2014), appear to exhibit declining oxygen consumption rates during progressive hypoxia. In this study we challenge the assumption that aerobic oxygen conforming fishes exist (Ultsch et al., 1981b; Steffensen, 2006), by testing the ability of the $S$. marmoratus, one of the few reported oxygen conformers, to maintain oxygen consumption during exposure to progressive hypoxia.

Fish regulate different physiological parameters to maintain their oxygen consumption to meet the oxygen demand determined by their metabolism (Jones et al., 1970; Jones, 1971). When exposed to moderate hypoxia most exclusive water-breathing fish increase transport of water over the gills (Randall \& Shelton, 1963; Wood \& Shelton, 1980; McKenzie et al., 1991) by increasing ventilation frequency and volume (Steffensen et al., 1982). When exposed to severe hypoxia, a decrease in heart rate (bradycardia) will occur with a concurrent increase in blood pressure that increases recruitment of gill lamellae as blood flows through the gills (Randall \& Shelton, 1963; McKenzie et al., 2007, 2009). Changes in oxygen binding properties of fish blood help facilitate oxygen uptake and delivery to tissues during hypoxia by increasing the oxygen affinity and carrying capacity of haemoglobin (Bohr et al., 1904; Root, 1931; Berenbrink, 2007; Rummer et al., 2013). In combination, these factors are instrumental in maintaining the capacity of an oxygen regulating fish to consume oxygen during hypoxia. By comparison, an oxygen conforming fish should lack one or more of these capabilities. However, even fish without haemoglobin (as well as salamanders, which are not capable of aquatic ventilation) have been shown to be aquatic oxygen regulators (Holeton, 1970; Hemmingsen et al., 1972; Ultsch \& Duke, 1990). While a few species, such as Acipenser naccarii Bonaparte

This article is protected by copyright. All rights reserved. 
1836 (McKenzie et al., 2001, 2007) and hellbender salamanders (Ultsch \& Duke, 1990), may be oxygen conforming under certain conditions (e.g., when prevented from swimming, thereby limiting convective oxygen transport), this situational dependency could mask the true ability of a species to regulate oxygen consumption and lead to erroneous conclusions of oxygen conforming. The purpose of this study was to affirm or dismiss oxygen conforming as a respiratory strategy in S. marmoratus; it has been reported to be both an oxygen conformer (Graham \& Baird, 1984; Graham, 1997) and an oxygen regulator (Bicudo \& Johansen, 1979). A total of 12 marbled swamp eels (body mass, mean \pm S.D. $=224 \pm 4.7 \mathrm{~g}$, range 160-328 g) were collected from natural ponds near Rio Claro, Brazil. All fish were caught by hand net and immediately transferred to the Rio Claro UNESP holding facility where individual fish were placed in a separate plastic flow-through aquarium. Being facultative air breathers, they had access to air when held in the aquaria and the flow-through water temperature was kept at a $23-26^{\circ} \mathrm{C}$ diurnal temperature variation similar to the collection ponds. All fish were kept under a natural $12 \mathrm{~h}$ light:12 $\mathrm{h}$ dark photoperiod.

Oxygen uptake $\left(\dot{M}_{\mathrm{O}_{2}}\right)$ during experimentation was measured using intermittentflow respirometry (Steffensen, 1989; Svendsen et al., 2016a, 2016b) controlled using AquaResp V1 (University of Copenhagen; www.aquaresp.com). Oxygen was measured using PreSens (Fibox 3, Presens; www.presens.de) oxygen sensors. Two identical 1.51 respirometers were constructed, using capped PVC tubing with an access lid, a recirculation loop for mixing and a flush chimney. The tubing was similar to tubing that fish voluntarily occupied in the holding facilities. Eheim (www.eheim.com) aquarium pumps (model 1046, $51 \mathrm{~min}^{-1}$ ) were used for recirculation and flushing, and the two respirometers were submerged in a 1001 tank with temperature-controlled and aerated fresh water. Water temperature was maintained at $26.0 \pm$ 
$0.1^{\circ} \mathrm{C}$ (mean \pm hysteresis), and $\dot{M}_{\mathrm{O}_{2}}$ was measured using $600 \mathrm{~s}$ flush, $60 \mathrm{~s}$ wait, and $600 \mathrm{~s}$ measurement (closed respirometer) loops. The fish had no access to air in the respirometers and they were allowed to acclimate in the respirometers for at least $12 \mathrm{~h}$ during which time oxygen uptake rate was recorded and used to determine the standard metabolic rate (SMR) (Beamish, 1964b). Following SMR recordings, hypoxia was induced to determine $\mathrm{pO}_{2 \text { crit }}$. This was done by pausing the intermittent flushing of the respirometer and allowing the fish to reduce the available oxygen in the respirometer from $c .18$ to $1.3 \mathrm{kPa}$. Inducing progressive hypoxia using this method increases $\mathrm{CO}_{2}$ levels as the fish respire (Malte et al., 2016; Snyder et al., 2016). A degree of hypercapnia must therefore have been present in the water during our experiments (Keys, 1930b; Piiper et al., 1971; Hughes, 1973; Piiper \& Scheid, 1984), but due to the fast induction of hypoxia this is not believed to have affected our results (Regan \& Richards, 2017). Additionally, the previous studies of hypoxia tolerance in Synbranchus marmoratus induced hypoxia using similar methods (Bicudo \& Johansen, 1979; Graham \& Baird, 1984), making our results directly comparable with these previous studies (Figure 1). The SMR was calculated by fitting a double Gaussian distribution to all measured $\dot{M}_{\mathrm{O}_{2}}$ data as described in Steffensen et al. (1994; Chabot et al., 2016). The critical oxygen tension was established using a protocol similar to that of Yeager and Ultsch (1989) but employing assumptions as in Chabot and Claireaux (2016), thus finding the intersection between constant SMR and a regression line representing oxygen conformation. After introduction to the respirometers, fish showed elevated $\dot{M}_{\mathrm{O}_{2}}$ up to $5 \mathrm{~h}$. The SMR of S. mamoratus in normoxia was $1.18 \pm 0.14 \mathrm{mmol} \mathrm{O}_{2} \mathrm{~h}^{-1} \mathrm{~kg}^{-1}$ (mean \pm S.D). During progressive hypoxia exposure the fish were able to maintain SMR or higher $\dot{M}_{\mathrm{O}_{2}}$ until a critical partial pressure $\left(\mathrm{pO}_{2 \text { crit }}\right)$ of $4.65 \pm 1.59 \mathrm{kPa}$ (mean \pm S.D) (Figure 1). The elevated $\dot{M}_{O_{2}}$ observed at moderate hypoxia is likely caused by spontaneous activity (Ott et al., 1980).

This article is protected by copyright. All rights reserved. 
Out of more than 30,000 known species of fish, only five (Acipenser spp., $S$. marmoratus, G. maculatus, C. batrachus and P. notatus) are at present thought to be oxygen conformers incapable of maintaining oxygen uptake under moderate hypoxia exposure (Singh \& Hughes, 1971; Burggren \& Randall, 1978; Graham \& Baird, 1984; Urbina et al., 2012; Tripathi et al., 2013). Here we examined the capacity of one of these supposedly unique species, $S$. marmoratus, to regulate their $\dot{M}_{O_{2}}$ under hypoxia. In contrast to previous conclusions by Graham (1997) and Graham and Baird (1984), this study supports the suggestion by Bicudo and Johansen (Bicudo \& Johansen, 1979), that S. marmoratus is indeed an oxygen regulator, with a $\mathrm{pO}_{2 \text { crit }}$ of $4.65 \pm 1.59 \mathrm{kPa}$. This value is similar to those for many freshwater and marine teleosts $[c .4-5$ kPa for 50 species reviewed by Rogers et al. 2016 (Ultsch et al., 1978, 1980; Bicudo \& Johansen, 1979; Thomas et al., 1988; Chabot \& Claireaux, 2008; Thuy et al., 2010)].

Although previous studies have suggested that oxygen conforming occurs in fishes, there are numerous indicators to suggest $S$. marmoratus and other species can regulate oxygen consumption in hypoxia. First, while Bicudo and Johansen (1979) and Graham and Baird (1984) disagreed to whether S. marmoratus was an oxygen regulator or conformer, they both found that it begins to rely on aerial respiration at an oxygen tension around 4-8.6 $\mathrm{kPa}$ depending on size (Figure $1 \mathrm{~b}$ ). This oxygen tension overlaps with the $\mathrm{pO}_{2 \text { crit }}$ determined in this study, suggesting that aerial respiration is a natural regulatory response (i.e., oxygen regulation via a change in oxygen medium) from the fish adapted for survival in waters with insufficient levels of oxygen to maintain aquatic respiration (Graham et al., 1977; Hughes and Singh, 1971).

A second rationale for the previous suggestion that S. marmoratus and other species are oxygen conformers may come from an inappropriate use of respirometry across a large size range of fish (Graham and Baird, 1984). Subsequent findings (Svendsen et al., 2016

This article is protected by copyright. All rights reserved. 
a,b) have shown that the respirometer-to-fish-volume ratio has a strong influence on the variation and thus the precision of measured oxygen uptake rate of the fish. This means that, if Graham and Baird used the same size respirometers for all of the different sized fish in their study (information not provided) they would have had significant variances in measurements. For the smallest fish in particular, respirometer-to-fish-volume ratios would have reached an excess of 3000 resulting in very uncertain determinations of $\dot{M}_{O_{2}}$ (Svendsen et al., 2016b). An example of this variance can be seen in Figure $1 \mathrm{a}$ as an overlap of the $\mathrm{SE}$ bars from normoxia down to a $\mathrm{pO}_{2}$ of $80 \mathrm{~mm} \mathrm{Hg}$. Graham and Baird (Graham \& Baird, 1984) pooled the data for both large and small fish, which might inadvertently have confounded data. Specifically, the largest airbreathing individuals included in the Graham and Baird (1984) study should be expected to have higher critical oxygen tensions than significantly smaller individuals (Babiker, 1979; Graham \& Baird, 1984) and pooling of data points are therefore likely to erroneously portray this species is oxygen conforming.

The definition of SMR is the minimum oxygen uptake of a post-absorptive ectothermic animal required to maintain and sustain life at a given temperature (Beamish, 1964a; Beamish \& Mookherjii, 1964). For an oxygen regulator, any deviations below SMR must infer a transition to anaerobic metabolism to fuel the processes of life (Hochachka \& Lutz, 2001; Pörtner \& Grieshaber, 1993). As anaerobic metabolism will cause a build-up of metabolic byproducts such as lactic acid, which is energetically costly to remove from the system (Hochachka \& Lutz, 2001), an increase in oxygen consumption during post-hypoxic recuperation will result (Scarabello et al., 1992; Lee et al., 2003). A true aerobic oxygen conformer would lower its metabolism, initially preventing this anaerobiosis (Pörtner and Grieshaber, 1993). For instance, in the study by Urbina and Glover (2012) which suggested G. maculatus to be an oxygen

This article is protected by copyright. All rights reserved. 
conformer, they also found their experimental fish to show a lactate build-up, indicative of anaerobiosis occurring in progressive hypoxia, as well as showing regulatory responses as increased levels of haemoglobin (Urbina and Glover, 2012) and increased ventilation (Urbina $e t$ al., 2011). Lastly, if SMR is not established in normoxia (Urbina et al., 2012; Urbina \& Glover, 2013), defining whether a fish is an oxygen regulator or conformer is rationally challenging. It is well known that to establish an accurate estimate of SMR a fish needs to be resting in the respirometer for a considerable time prior to data collection (Keys, 1930b; Snyder et al. 2016; Steffensen, 2002; Chabot et al. 2016). If measurements in hypoxia are initiated too early during the resting period, or in a period of spontaneous activity, the fish will not be truly resting, its metabolism will be elevated above SMR and it will therefore appear to be an oxygen conformer when the oxygen tension in the water is lowered (Pörtner \& Grieshaber, 1993; Ultsch et al., 1981). Spontaneous activity of the fish has previously been attributed as an explanation for the early suggestion that the toadfish Opsanus tau (L. 1758) be an oxygen conformer (Hall, 1929) rather than an oxygen regulator as determined by Ultsch et al. (1981). The same rationale (Ott et al., 1980) has been applied to the findings for P. notatus (Craig et al., 2014; LeMoine et al., 2014). Similarly, C. batrachus, an air-breathing fish, has been shown to be an oxygen regulator (Jordan, 1976) as well as a conformer (Singh \& Hughes, 1971; Tripathi et al., 2013), although two of these studies documented regulatory behaviour including increased ventilation frequency (Singh \& Hughes, 1971; Jordan, 1976) while the third (Tripathi et al. 2013) only reported oxygen uptake rate values from a limited range of oxygen levels. Clearly, experimental artefacts are likely to have driven some of the initial erroneous conclusions relating to oxygen conforming in bony fishes.

This article is protected by copyright. All rights reserved. 
The results presented here remove one of the last remaining species of bony fish from the list of oxygen conformers and provides support to the theory that all bony fishes are oxygen regulators (Keys, 1930b; Ultsch et al., 1981a; Steffensen, 2006). Only two bony fishes now remain on the list of potential oxygen conformers ( $P$. notatus and G. maculatus), but telltale regulatory responses and anaerobiosis during hypoxia (G. maculatus) and possible experimental artefacts (P. notatus; Craig et al., 2014; Pörtner \& Grieshaber, 1993; Urbina et al., 2011, 2012) also begs the question of whether these species are in fact oxygen regulators.

\section{REFERENCES}

Babiker, M. M. (1979) Respiratory Behaviour, Oxygen Consumption and Relative Dependence on Aerial Respiration in the African Lungfish (Protopterus Annectens, Owen) and an Air-Breathing Teleost (Clarias lazera C.). Hydrobiologia 65, 177-187.

Beamish, F. W. H. (1964a) Influence of Starvation on Standard and Routine Oxygen Consumption. Transactions of the American Fisheries Society 93, 103-107.

Beamish, F. W. H. (1964b) Respiration of Fishes with Special Emphasis on Standard Oxygen Consumption: II. Influence of Weight and Temperature on Respiration of Several Species. Canadian Journal of Zoology 42, 177-188.

Beamish, F. W. H. \& Mookherjii, P. S. (1964) Respiration of Fishes with Special Emphasis on Standard Oxygen Consumption: I. Influence of Weight and Temperature on Respiration

This article is protected by copyright. All rights reserved. 
of Goldfish, Carassius Auratus L. Canadian Journal of Zoology 42, 161-175.

Berenbrink, M. (2007) Historical Reconstructions of Evolving Physiological Complexity: O2 Secretion in the Eye and Swimbladder of Fishes. Journal of Experimental Biology 210, $1641-1652$.

Bicudo,J. E. P. W. \& Johansen, K. (1979) Respiratory Gas Exchange in the Airbreathing Fish, Synbranchus marmoratus. Environmental Biology of Fishes 4, 55-64.

Bohr, C., Hasselbalch, K. \& Krogh, A. (1904) Ueber Einen in Biologischer Beziehung Wichtigen Einfluss, Den Die Kohlensäurespannung Des Blutes Auf Dessen Sauerstoffbindung Übt1. Skandinavisches Archiv für Physiologie 16, 402-412.

Burggren, W. W. \& Randall, D. J. (1978) Oxygen Uptake and Transport during Hypoxic Exposure in the Sturgeon Acipenser Transmontanus. Respiration Physiology 34, 171183.

Chabot, D. \& Claireaux, G. (2008) Environmental Hypoxia as a Metabolic Constraint on Fish: The Case of Atlantic Cod, Gadus morhua. Marine Pollution Bulletin 57, 287-294.

Chabot, D., Steffensen, J. F. \& Farrell, A. P. (2016) The Determination of Standard Metabolic Rate in Fishes. Journal of Fish Biology 88, 81-121.

This article is protected by copyright. All rights reserved. 
Claireaux, G. \& Chabot, D. (2016) Responses by Fishes to Environmental Hypoxia: Integration through Fry’s Concept of Aerobic Metabolic Scope. Journal of Fish Biology 88, 232251.

Craig, P. M., Fitzpatrick, J. L., Walsh, P. J., Wood, C. M. \& McClelland, G. B. (2014) Coping with Aquatic Hypoxia: How the Plainfin Midshipman (Porichthys notatus) Tolerates the Intertidal Zone. Environmental Biology of Fishes 97, 163-172.

Graham, J. B. (1997) Air-Breathing Fishes: Evolution, Diversity, and Adaptation. Academic Press.

Graham, J. B. \& Baird, T. A. (1984) The Transition to Air Breathing in Fishes: III. Effects of Body Size and Aquatic Hypoxia on the Aerial Gas Exchange of the Swamp Eel Synbranchus Marmoratus. Journal of Experimental Biology 108, 357-375.

Hall, F. G. (1929) The Influence of Varying Oxygen Tensions Upon the Rate of Oxygen Consumption in Marine Fishes. American Journal of Physiology -- Legacy Content 88, $212-218$.

Hemmingsen, E. A., Douglas, E. L., Johansen, K. \& Millard, R. W. (1972) Aortic Blood Flow and Cardiac Output in the Hemoglobin-Free Fish Chaenocephalus aceratus. Comparative Biochemistry and Physiology A 43, 1045-1051.

This article is protected by copyright. All rights reserved. 
Hochachka, P. W. \& Lutz, P. L. (2001) Mechanism, Origin, and Evolution of Anoxia Tolerance in Animals 论. Comparative Biochemistry and Physiology B 130, 435-459.

Holeton, G. F. (1970) Oxygen Uptake and Circulation by a Hemoglobinless Antarctic Fish (Chaenocephalus aceratus Lönnberg) Compared with Three Red-Blooded Antartic Fish. Comparative Biochemistry and Physiology 34, 457-471.

Hughes, G. M. (1973) Respiratory Responses to Hypoxia in Fish. American Zoologist 13, 475489.

Jones, D. R. (1971) Theoretical Analysis of Factors Which May Limit the Maximum Oxygen Uptake of Fish: The Oxygen Cost of the Cardiac and Branchial Pumps. Journal of Theoretical Biology 32, 341-349.

Jones, D. R., Randall, D. J. \& Jarman, G. M. (1970) A Graphical Analysis of Oxygen Transfer in Fish. Respiration Physiology 10, 285-298.

Jordan, J. (1976) The Influence of Body Weight on Gas Exchange in the Air-Breathing Fish, Clarias Batrachus. Comparative Biochemistry and Physiology A 53, 305-310.

Keys, A. B. (1930a) The Measurement of the Respiratory Exchange of Aquatic Animals. The Biological Bulletin 59, 187-198.

This article is protected by copyright. All rights reserved. 
Keys, A. B. (1930b) The Relation of the Oxygen Tension in the External Respiratory Medium to the Oxygen Consumption of Fishes. Science 71, 195-196.

LeMoine, C. M. R., Bucking, C., Craig, P. M. \& Walsh, P. J. (2014) Divergent Hypoxia Tolerance in Adult Males and Females of the Plainfin Midshipman (Porichthys notatus). Physiological \& Biochemical Zoology 87, 325-333.

Malte, C. L., Nørgaard, S. \& Wang, T. (2016) Closed System Respirometry May Underestimate Tissue Gas Exchange and Bias the Respiratory Exchange Ratio (RER). Comparative Biochemistry and Physiology A 192, 17-27.

McKENZIE, D. J., Burleson, M. L. \& Randall, D. J. (1991) The Effects of Branchial Denervation and Pseudobranch Ablation on Cardioventilatory Control in an AirBreathing Fish. Journal of Experimental Biology 161, 347-365.

McKenzie, D. J., Cataldi, E., Romano, P., Owen, S. F. \& al, et. (2001) Effects of Acclimation to Brackish Water on the Growth, Respiratory Metabolism, and Swimming Performance of Young-of-the-Year Adriatic Sturgeon (Acipenser naccarii). Canadian Journal of Fisheries and Aquatic Sciences 58, 1104-1112.

McKenzie, D. J., Steffensen, J. F., Korsmeyer, K., Whiteley, N. M., Bronzi, P. \& Taylor, E. W. (2007) Swimming Alters Responses to Hypoxia in the Adriatic Sturgeon Acipenser

This article is protected by copyright. All rights reserved. 
naccarii. Journal of Fish Biology 70, 651-658.

McKenzie, D. J., Shingles, A., Claireaux, G. \& Domenici, P. (2009) Sublethal Concentrations of Ammonia Impair Performance of the Teleost Fast-Start Escape Response. Physiological \& Biochemical Zoology 82, 353-362.

Ott, M. E., Heisler, N. \& Ultsch, G. R. (1980) A Re-Evaluation of the Relationship between Temperature and the Critical Oxygen Tension in Freshwater Fishes. Comparative Biochemistry and Physiology Part A: Physiology 67, 337-340.

Piiper, J. \& Scheid, P. (1984) 4 Model Analysis of Gas Transfer in Fish Gills. In Fish Physiology (W.S. Hoar and D.J. Randall, ed), Gills Anatomy, Gas Transfer, and Acid-Base Regulation, pp. 229-262 Academic Press.

Piiper, J., Dejours, P., Haab, P. \& Rahn, H. (1971) Concepts and Basic Quantities in Gas Exchange Physiology. Respiration Physiology 13, 292-304.

Pörtner, H. O. \& Grieshaber, M. K. (1993) Critical Po2(s) in Oxyconforming and Oxyregulating Animals: Gas Exchange, Metabolic Rate and the Mode of Energy Production. In The vertebrate gas transport cascade adaptations to environment and mode of life ( $J E P W$ Bicudo, ed ), pp. 330 -357. Boca Raton, FL: CRC Press,

Randall, D. . \& Shelton, G. (1963) The Effects of Changes in Environmental Gas Concentrations on the Breathing and Heart Rate of a Teleost Fish. Comparative Biochemistry and

This article is protected by copyright. All rights reserved. 
Physiology 9, 229-239.

Regan, M. D. \& Richards, J. G. (2017) Rates of Hypoxia Induction Alter Mechanisms of $\mathrm{O}_{2}$ Uptake and the Critical $\mathrm{O}_{2}$ Tension of Goldfish. Journal of Experimental Biology jeb. 154948.

Rogers, N. J., Urbina, M. A., Reardon, E. E., McKenzie, D. J. \& Wilson, R. W. (2016) A New Analysis of Hypoxia Tolerance in Fishes Using a Database of Critical Oxygen Level

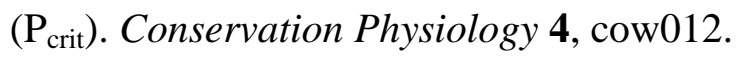

Root, R. W. (1931) The Respiratory Function of the Blood of Marine Fishes. The Biological Bulletin 61, 427-456.

Rummer, J. L., McKenzie, D. J., Innocenti, A., Supuran, C. T. \& Brauner, C. J. (2013) Root Effect Hemoglobin May Have Evolved to Enhance General Tissue Oxygen Delivery. Science 340, 1327-1329.

Singh, B. N. \& Hughes, G. M. (1971) Respiration of an Air-Breathing Catfish Clarias Batrachus (Linn.). Journal of Experimental Biology 55, 421-434.

Snyder, S., Nadler, L., Domenici, P., Bayley, J., Johansen, J. L., Svendsen, M. B. \& Steffensen, J. F. (2016) Effect of Closed versus Intermittent-Flow Respirometry on Hypoxia

This article is protected by copyright. All rights reserved. 
Tolerance in Aquatic Breathers. Journal of Fish Biology 88, 252 - 264.

Steffensen, J. F. (1989) Some Errors in Respirometry of Aquatic Breathers: How to Avoid and Correct for Them. Fish Physiology and Biochemistry 6, 49-59.

Steffensen, J. F. (2002) Metabolic Cold Adaptation of Polar Fish Based on Measurements of Aerobic Oxygen Consumption: Fact or Artefact? Artefact! Comparative Biochemistry and Physiology A 132, 789-795.

Steffensen, J. F. (2006) Oxygen Consumption of Fish Exposed to Hypoxia: Are They All Oxyregulators or Are Any Oxyconformers? Fish Physiology, Toxicology, and Water Quality 239. , 239-250.

Steffensen, J. F., Lomholt, J. P. \& Johansen, K. (1982) Gill Ventilation and O2 Extraction during Graded Hypoxia in Two Ecologically Distinct Species of Flatfish, the Flounder (Platichthys flesus) and the Plaice (Pleuronectes platessa). Environmental Biology of Fishes 7, 157-163.

Steffensen, J. F., Bushnell, P. G. \& Schurmann, H. (1994) Oxygen Consumption in Four Species of Teleosts from Greenland: No Evidence of Metabolic Cold Adaptation. Polar Biology 14, 49-54.

This article is protected by copyright. All rights reserved. 
Svendsen, M. B. S., Bushnell, P. G. \& Steffensen, J. F. (2016a) Design and Setup of Intermittent-Flow Respirometry System for Aquatic Organisms. Journal of Fish Biology 88, 26-50.

Svendsen, M. B. S., Bushnell, P. G., Christensen, E. a. F. \& Steffensen, J. F. (2016b) Sources of Variation in Oxygen Consumption of Aquatic Animals Demonstrated by Simulated Constant Oxygen Consumption and Respirometers of Different Sizes. Journal of Fish Biology 88, 51-64.

Tang, P.-S. (1933) On the Rate of Oxygen Consumption by Tissues and Lower Organisms as a Function of Oxygen Tension. The Quarterly Review of Biology 8, 260-274.

Thomas, S., Fievet, B., Claireaux, G. \& Motais, R. (1988) Adaptive Respiratory Responses of Trout to Acute Hypoxia. I. Effects of Water Ionic Composition on Blood Acid-Base Status Response and Gill Morphology. Respiration Physiology 74, 77-89.

Thuy, N. H., Tien, L. A., Tuyet, P. N., Huong, D. T. T., Cong, N. V., Bayley, M., Wang, T. \& Lefevre, S. (2010) Critical Oxygen Tension Increases during Digestion in the Perch Perca fluviatilis. Journal of Fish Biology 76, 1025-1031.

Tripathi, R., Mohindra, V., Singh, A., Kumar, R., Mishra, R. \& Jena, J. (2013) Physiological Responses to Acute Experimental Hypoxia in the Air-Breathing Indian Catfish, Clarias

This article is protected by copyright. All rights reserved. 
batrachus (Linnaeus, 1758). Journal of Biosciences 38, 373-383.

Ultsch, G. R. \& Duke, J. T. (1990) Gas Exchange and Habitat Selection in the Aquatic Salamanders Necturus maculosus and Cryptobranchus alleganiensis. Oecologia 83, $250-258$.

Ultsch, G. R., Boschung, H. \& Ross, M. J. (1978) Metabolism, Critical Oxygen Tension, and Habitat Selection in Darters (Etheostoma). Ecology 59, 99-107.

Ultsch, G. R., Ott, M. E. \& Heisler, N. (1980) Standard Metabolic Rate, Critical Oxygen Tension, and Aerobic Scope for Spontaneous Activity of Trout (Salmo gairdneri) and Carp (Cyprinus carpio) in Acidified Water. Comparative Biochemistry and Physiology A 67, 329-335.

Ultsch, G. R., Jackson, D. C. \& Moalli, R. (1981) Metabolic Oxygen Conformity among Lower Vertebrates: The Toadfish Revisited. Journal of comparative physiology 142, 439-443.

Urbina, M. A. \& Glover, C. N. (2012) Should I Stay or Should I Go?: Physiological, Metabolic and Biochemical Consequences of Voluntary Emersion upon Aquatic Hypoxia in the Scaleless Fish Galaxias maculatus. Journal of Comparative Physiology B 182, 10571067.

This article is protected by copyright. All rights reserved. 
Urbina, M. A. \& Glover, C. N. (2013) Relationship between Fish Size and Metabolic Rate in the Oxyconforming Inanga Galaxias maculatus Reveals Size-Dependent Strategies to Withstand Hypoxia. Physiological and Biochemical Zoology 86, 740-749.

Urbina, M. A., Forster, M. E. \& Glover, C. N. (2011) Leap of Faith: Voluntary Emersion Behaviour and Physiological Adaptations to Aerial Exposure in a Non-Aestivating Freshwater Fish in Response to Aquatic Hypoxia. Physiology \& Behavior 103, 240247.

Urbina, M. A., Glover, C. N. \& Forster, M. E. (2012) A Novel Oxyconforming Response in the Freshwater Fish Galaxias maculatus. Comparative Biochemistry and Physiology A 161, $301-306$.

Wood, C. M. \& Shelton, G. (1980) The Reflex Control of Heart Rate and Cardiac Output in the Rainbow Trout: Interactive Influences of Hypoxia, Haemorrhage, and Systemic Vasomotor Tone. Journal of Experimental Biology 87, 271-284.

This article is protected by copyright. All rights reserved. 

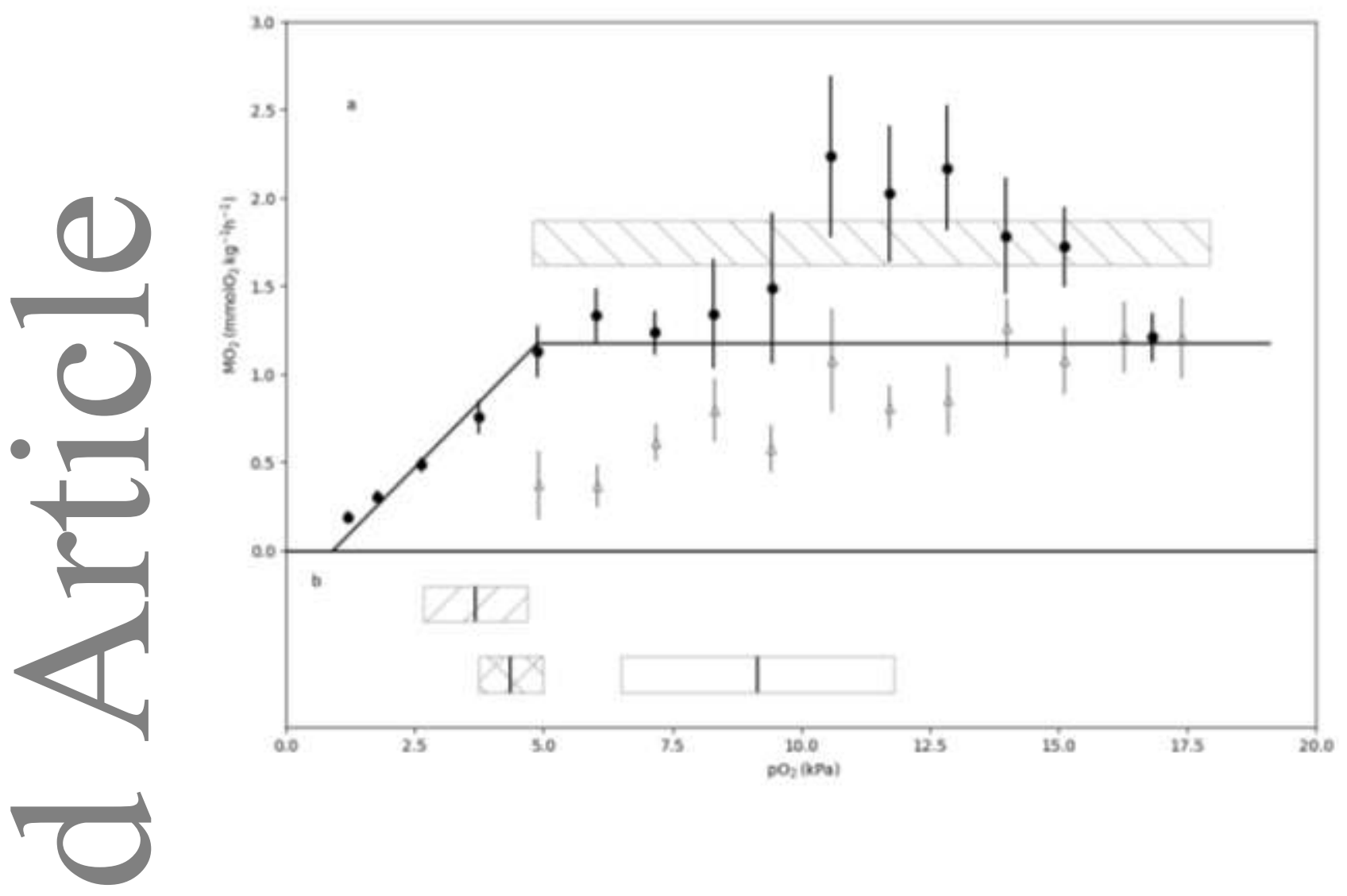

Figure 1 (a) Mean $\left(\bullet, \pm 95 \%\right.$ C.I.) oxygen uptake $\left(\dot{M}_{\mathrm{O}_{2}}\right)$ rate Synbranchus marmoratus exposed to progressive hypoxia. The standard metabolic rate was found to be $1.18 \pm 0.14 \mathrm{mmol} \mathrm{O}_{2} \mathrm{~h}^{-1} \mathrm{~kg}^{-1}$ $\left(\right.$ mean \pm S.D) at a water oxygen partial pressure $\left(\mathrm{pO}_{2}\right)$ of $18 \mathrm{kPa}$, and the critical oxygen tension $\left(\mathrm{pO}_{2 c r i t}\right)$ $4.65 \pm 1.59 \mathrm{kPa}($ mean \pm S.D). - , theoretical curve for an oxygen regulator with an SMR of 1.19 mmol O $\mathrm{h}^{-1} \mathrm{~kg}^{-1}$ and a $\mathrm{pO}_{2 \text { crit }}$ of $4.66 \mathrm{~mm} \mathrm{Hg} ; \triangle$, the reported values (means $\pm \mathrm{S}$.E.) from figure 2 in Graham and Baird (1984); Johansen (1979). (b) The transition to air breathing for S. marmoratus; the top row is from Bicudo and Johansen (1979), average fish mass $117.9 \mathrm{~g}$; the bottom row is from Graham and Baird (1984), average fish mass $151.8 \mathrm{~g}$ (hatched) or $722.9 \mathrm{~g}$ (unhatched).

This article is protected by copyright. All rights reserved. 